NBER WORKING PAPER SERIES

THE EXTENSIVE MARGIN, SECTORAL SHARES AND INTERNATIONAL BUSINESS CYCLES

Michael B. Devereux

Viktoria Hnatkovska

Working Paper 17289

http://www.nber.org/papers/w17289

\author{
NATIONAL BUREAU OF ECONOMIC RESEARCH \\ 1050 Massachusetts Avenue \\ Cambridge, MA 02138
}

August 2011

Hnatkovska thanks SSRHS for research support. Devereux thanks SSRHC, the Bank of Canada, and the Royal Bank of Canada for financial support. The opinions expressed in this paper are those of the authors alone and cannot be ascribed to the Bank of Canada or the National Bureau of Economic Research.

NBER working papers are circulated for discussion and comment purposes. They have not been peerreviewed or been subject to the review by the NBER Board of Directors that accompanies official NBER publications.

(C) 2011 by Michael B. Devereux and Viktoria Hnatkovska. All rights reserved. Short sections of text, not to exceed two paragraphs, may be quoted without explicit permission provided that full credit, including (C) notice, is given to the source. 
The Extensive Margin, Sectoral Shares and International Business Cycles

Michael B. Devereux and Viktoria Hnatkovska

NBER Working Paper No. 17289

August 2011

JEL No. F3,F4

\begin{abstract}
This paper documents some previously neglected features of sectoral shares at business cycle frequencies in OECD economies. In particular, we find that the nontraded sector share of output is as volatile as aggregate GDP, and that for most countries, the nontraded sector is distinctly countercyclical. While the standard international real business cycle model has difficulty in accounting for these properties of the data, an extended model which allows for sectoral adjustment along both the intensive and extensive margins does a much better job in replicating the volatilities and co-movements in the data. In addition, the model provides a closer match between theory and data with respect to the correlation between relative consumption growth and real exchange rate changes, a key measure of international risk-sharing.
\end{abstract}

Michael B. Devereux

Department of Economics

University of British Columbia

997-1873 East Mall

Vancouver, BC V6T 1Z1

CANADA

and NBER

mbdevereux@gmail.com

Viktoria Hnatkovska

Department of Economics

University of British Columbia

Vancouver, BC V6T 1Z1

hnatkovs@interchange.ubc.ca 


\title{
The Extensive Margin, Sectoral Shares and International Business Cycles*
}

\author{
Michael B. Devereux and Viktoria Hnatkovska ${ }^{\dagger}$
}

\begin{abstract}
This paper documents some previously neglected features of sectoral shares at business cycle frequencies in OECD economies. In particular, we find that the nontraded sector share of output is as volatile as aggregate GDP, and that for most countries, the nontraded sector is distinctly countercyclical. While the standard international real business cycle model has difficulty in accounting for these properties of the data, an extended model which allows for sectoral adjustment along both the intensive and extensive margins does a much better job in replicating the volatilities and co-movements in the data. In addition, the model provides a closer match between theory and data with respect to the correlation between relative consumption growth and real exchange rate changes, a key measure of international risk-sharing.
\end{abstract}

JEL classification: C51; C52

Keywords: nontraded goods, sectoral shares

\section{Introduction}

Output shares of traded and nontraded goods sectors have been changing secularly over time. As is well known, the service sector has experienced secular expansion,

${ }^{*}$ Hnatkovska thanks SSRHS for research support. Devereux thanks SSRHC, the Bank of Canada, and the Royal Bank of Canada for financial support. The opinions expressed in this paper are those of the authors alone and cannot be ascribed to the Bank of Canada.

${ }^{\dagger}$ Department of Economics, University of British Columbia, 997 - 1873 East Mall, Vancouver, BC V6T 1Z1, Canada. E-mail addresses: hnatkovs@mail.ubc.ca (Hnatkovska), mbdevereux@gmail.com (Devereux). 
while traditional sectors, such as manufacturing and agriculture, have contracted. In addition to this well-recognized long-run structural change however, output shares of the traded and nontraded sectors has shown significant business cycle movements. This paper studies the business cycle properties of traded and nontraded goods sectors. We first document that the standard deviation of nontraded output share is around 2.3 percent in a sample of OECD countries during 1970-2007 period. Nontraded output share is at least as volatile as aggregate output. In addition, we find that nontraded output share is strongly countercyclical for almost all countries. We then construct a theoretical model to account for these properties.

Fluctuations in the nontraded output share can be due to changes at the intensive margin as existing firms in different sectors adjust their output in response to sectoral demand and supply conditions; or due to the changes at the extensive margin that occur due to the emergence of new firms, or firms reallocating across sectors. Existing literature has focused on the intensive margin, and has had difficulty in matching the volatility and cyclicality of sectoral output shares. In this paper we first document this disagreement between theory and data, and then provide an extension of the standard framework to account for empirical regularities. In particular, we extend a standard two-sector international business cycle model to allow for firm heterogeneity and an extensive margin in sectoral reallocations. This framework allows us to quantify the contribution of each margin to sectoral output volatility and co-movement. We also investigate the role played by the extensive margin in sectoral reallocation for international business cycles and cross country risk-sharing.

We start by documenting the properties of the nontraded output share in a conventional two-sector model of international business cycles. We show that this model does a poor job in matching the regularities we documented above. We proceed by extending this benchmark framework to allow for an extensive margin in sectoral adjustments. In particular, we introduce endogenous tradability, where in response to sector-specific shocks, firms decide which sector to locate in. These decisions to re-allocate across sectors are driven by profit maximization of heterogenous firms, subject to international transportation costs and fixed costs of exporting. We show that in the presence of endogenous tradability the performance of our model improves on several dimensions. First, it produces a more volatile nontraded output share as firms shift across sectors in response to productivity shocks. Second, the model produces a countercyclical nontraded output share, consistent with the data. Finally, the model 
is able to improve on a number of business cycles moments, and in particular, the model does a better job at explaining the observed consumption real exchange rate correlation than does the standard model. Thus, the extensive margin of adjustment provides a better model for understanding the pattern of international consumption risk sharing.

\section{Empirical facts}

We report the properties of the nontraded output share using the OECD STAN database for the 1970-2007 period. Nontraded output is defined based on the traditional industrial classification, according to United Nations classification system. The distribution of sectors into tradables and nontradables is summarized in Table 1 . The nontradable share is constructed as the ratio of nontraded output to aggregate output for each country.

Table 1: Classification of sectors by tradability

\begin{tabular}{lc}
\hline \hline Sector & Classification \\
\hline Manufacturing & $\mathrm{T}$ \\
Agriculture, hunting, forestry and fishing & $\mathrm{T}$ \\
Mining and quarrying & $\mathrm{T}$ \\
Wholesale and retail trade - restaurants and hotels & $\mathrm{T}$ \\
Transport, storage and communications & $\mathrm{T}$ \\
Electricity, gas and water supply & $\mathrm{N}$ \\
Finance, insurance, real estate, and business services & $\mathrm{N}$ \\
Construction & $\mathrm{N}$ \\
Community, social, and personal services & $\mathrm{N}$ \\
\hline \hline
\end{tabular}

Figure 1 illustrates some of our findings. The figure illustrates the cyclical components of aggregate output, nontraded and traded output, and the nontraded output share for the U.S. during the1987-2007 period. Clearly, the nontraded output share is volatile (equally as volatile as nontraded output itself), and strongly countercyclical.

This result for the U.S. is confirmed in a broader sample of OECD countries. Table 2 summarizes our findings by reporting the standard deviation of the nontraded output share (column (i)), its correlation with aggregate output (column (ii)), and the standard deviation of aggregate output (column (iii)). ${ }^{1}$ All countries exhibit sig-

\footnotetext{
${ }^{1}$ All series are HP-filtered with smoothing parameter 100.
} 
Figure 1: Cyclical component of aggregate, T, N output and $\mathrm{N}$ share

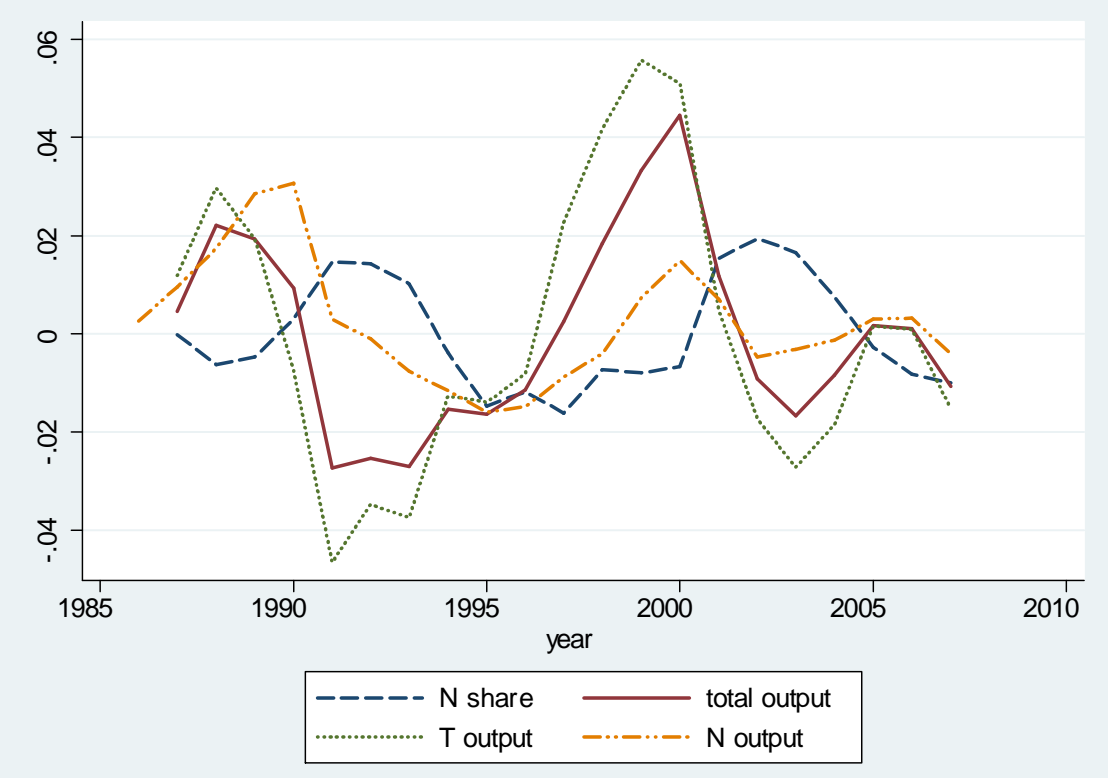

Notes: This figure presents the cyclical component of aggregate output, its traded and nontraded components, as well as nontraded share in the U.S. All series are HP-filtered.

nificant volatility of the nontraded output share at the business cycle frequency. The average standard deviation of nontraded output's share across countries is 2.26 percent. Note that this volatility is comparable to the volatility of aggregate output for our sample of countries. Furthermore, the nontraded output share is countercyclical for the vast majority of countries in the sample. The average correlation of the share of nontraded goods with aggregate output is -0.28 .

Having established these basic properties of the data, we now turn to a theoretical model which can be used in accounting for the empirical regularities.

\section{Model}

We consider a conventional two-country model with incomplete asset markets. This type of model has been used extensively in the literature to study the properties of international business cycles and cross country risk sharing. A world economy in our model consists of two symmetric economies, home $(\mathrm{H})$ and foreign (F). Each country is populated by a continuum of firms and households. We describe the problem faced 
Table 2: Variability of N output share, OECD 1970-2007

\begin{tabular}{|c|c|c|c|}
\hline country & $\begin{array}{c}\text { std.dev. }\left(Y^{N} \text { share) }\right. \\
\text { (i) }\end{array}$ & $\begin{array}{c}\operatorname{corr}\left(Y^{N} \text { share, } \ln Y\right) \\
\text { (ii) }\end{array}$ & $\begin{array}{l}\text { std.dev. }(Y) \\
\text { (iii) }\end{array}$ \\
\hline Austria & 0.01 & -0.61 & 0.01 \\
\hline Belgium & 0.02 & -0.62 & 0.02 \\
\hline Canada & 0.03 & & \\
\hline Czech Republic & 0.02 & -0.25 & 0.02 \\
\hline Denmark & 0.02 & -0.10 & 0.02 \\
\hline Finland & 0.03 & -0.28 & 0.04 \\
\hline France & 0.01 & -0.37 & 0.02 \\
\hline Germany & 0.02 & -0.67 & 0.02 \\
\hline Greece & 0.01 & -0.29 & 0.01 \\
\hline Hungary & 0.05 & & \\
\hline Iceland & 0.03 & & \\
\hline Italy & 0.02 & -0.49 & 0.02 \\
\hline Japan & 0.02 & 0.01 & 0.02 \\
\hline Korea & 0.05 & -0.06 & 0.03 \\
\hline Luxembourg & 0.02 & 0.78 & 0.03 \\
\hline Netherlands & 0.02 & & \\
\hline New Zealand & 0.03 & & \\
\hline Norway & 0.03 & 0.01 & 0.02 \\
\hline Poland & 0.03 & & \\
\hline Portugal & 0.03 & & \\
\hline Slovak Republic & 0.03 & & \\
\hline Spain & 0.02 & & \\
\hline Sweden & 0.02 & -0.65 & 0.02 \\
\hline Switzerland & 0.01 & -0.50 & 0.02 \\
\hline United Kingdom & 0.02 & & \\
\hline United States & 0.01 & -0.40 & 0.02 \\
\hline Average & 0.023 & -0.28 & 0.022 \\
\hline
\end{tabular}

by each agent type next.

\subsection{Households}

Households residing in country $\mathrm{H}$ supply $L^{\mathrm{H}}$ units of labor inelastically to domestic firms in return for the wage rate $w_{t}$. We assume that labor is perfectly mobile across sectors within a country, but not across countries. Households derive utility from consuming two goods: a composite tradable, $C^{\mathrm{T}}$ and a domestic nontradable, $C^{\mathrm{N}}$. In particular, preferences of $\mathrm{H}$ households are given by:

$$
\mathbb{E}_{t} \sum_{s=0}^{\infty} \delta^{s} U\left(C_{t+s}^{\mathrm{T}}, C_{t+s}^{\mathrm{N}}\right)
$$

where $0<\delta<1$ is the discount factor, and $U($.$) is a concave sub-utility function.$ Let all goods available to $\mathrm{H}$ households in period $t$ be normalized to a $[0,1]$ interval. We denote each individual good on this interval by index $i$. Further, let $i_{t}^{*}$ denote the endogenous time- $t$ share of goods that are non-traded. Then, at time $t$ household 
consumes a nontraded goods basket defined over a continuum of goods $I_{t}^{\mathrm{N}}=\left[0, i_{t}^{*}\right]$ and a traded goods basket defined over a continuum of goods $I_{t}^{\mathrm{T}}=\left[i_{t}^{*}, 1\right]$. In what follows we show that the measures of $I_{t}^{\mathrm{T}}$ and $I_{t}^{\mathrm{N}}$ are determined from the firms' profit maximizing decisions. The utility function of $\mathrm{H}$ household can be written as:

$$
U\left(C_{t}^{\mathrm{T}}, C_{t}^{\mathrm{N}}\right)=\frac{1}{1-\omega}\left(\left[\lambda_{\mathrm{T}}\left(i_{t}^{*}\right)^{1-\phi}\left(C_{t}^{\mathrm{T}}\right)^{\phi}+\lambda_{\mathrm{N}}\left(i_{t}^{*}\right)^{1-\phi}\left(C_{t}^{\mathrm{N}}\right)^{\phi}\right]^{\frac{1}{\phi}}\right)^{1-\omega}
$$

where $\omega$ is the inverse of the intertemporal elasticity. Here $\lambda_{\mathrm{T}}\left(i_{t}^{*}\right)$ and $\lambda_{\mathrm{N}}\left(i_{t}^{*}\right)=$ $1-\lambda_{\mathrm{T}}\left(i_{t}^{*}\right)$ are the weights of tradable and nontradable consumption in the aggregate consumption basket; and are endogenous functions $i_{t}^{*}$. In the Appendix A.2 we show that $\lambda_{\mathrm{N}}\left(i_{t}^{*}\right)=i_{t}^{*}$ and $\lambda_{\mathrm{T}}\left(i_{t}^{*}\right)=1-i_{t}^{*}$. The elasticity of substitution between tradable and nontradable consumption is $(1-\phi)^{-1}>0$.

A composite tradable good, $C_{t}^{\mathrm{T}}$, is given by a CES aggregator over tradables produced in the $\mathrm{H}$ and $\mathrm{F}$ countries:

$$
C_{t}^{\mathrm{T}}=\left[\lambda_{\mathrm{H}}\left(i_{t}^{*}\right)^{1-\rho}\left(C_{t}^{\mathrm{H}}\right)^{\rho}+\lambda_{\mathrm{F}}\left(i_{t}^{*}\right)^{1-\rho}\left(C_{t}^{\mathrm{F}}\right)^{\rho}\right]^{\frac{1}{\rho}}
$$

where $(1-\rho)^{-1}>0$ is the elasticity of substitution between tradable goods. Here $\lambda_{\mathrm{H}}\left(i_{t}^{*}\right)$ and $\lambda_{\mathrm{F}}\left(i_{t}^{*}\right)=1-\lambda_{\mathrm{H}}\left(i_{t}^{*}\right)$ denote the weights that households in country $\mathrm{H}$ assign to the consumption of $\mathrm{H}$ and F-produced tradable goods. Again, these weights are endogenously linked to the shares of non-traded goods in the two countries as:

$$
\lambda_{\mathrm{H}}\left(i_{t}^{*}\right)=\frac{1-i_{t}^{*}}{2-i_{t}^{*}-\hat{\imath}_{t}^{*}} \quad \text { and } \quad \lambda_{\mathrm{F}}\left(i_{t}^{*}\right)=\frac{1-\hat{\imath}_{t}^{*}}{2-i_{t}^{*}-\hat{\imath}_{t}^{*}},
$$

where $\hat{\imath}_{t}^{*}$ is the nontraded share in country $\mathrm{F}$ in period $t$. Hereafter we will use a hat, "^", over a variable to denote F country variables.

The key feature that distinguishes the preference structure outlined above from the one used commonly in the open-economy macro models is the endogenous nature of consumption expenditure weights. This is the outcome of the endogenous tradability feature of our model.

Each consumption basket is a CES aggregate of individual goods. For instance, period- $t$ consumption aggregates in country $\mathrm{H}$ are given by: 


$$
\begin{array}{rlrl}
\left(C_{t}^{\mathrm{N}}\right)^{\rho} & =\int_{0}^{i_{t}^{*}}\left(\frac{1}{i_{t}^{*}}\right)^{1-\rho} c_{t}(i)^{\rho} d i, & & i \in I^{\mathrm{N}} \\
\left(C_{t}^{\mathrm{H}}\right)^{\rho}=\int_{i_{t}^{*}}^{1}\left(\frac{1}{1-i_{t}^{*}}\right)^{1-\rho} c_{t}(i)^{\rho} d i, & & i \in I^{\mathrm{T}} \\
\left(C_{t}^{\mathrm{F}}\right)^{\rho} & =\int_{1}^{2-\hat{\imath}_{t}^{*}}\left(\frac{1}{1-\hat{\imath}_{t}^{*}}\right)^{1-\rho}\left(c_{t}^{*}(i)\right)^{\rho} d i . & & i \in I^{\mathrm{T}}
\end{array}
$$

See Appendix A.2 for the full derivations. Note also that by defining consumption aggregates in this way we rule out "love for variety" effects, which are characteristic of Dixit-Stiglitz aggregators. In doing so we follow the tradition of the standard international business cycle models, in which consumption aggregates are defined over a constant measure of varieties. ${ }^{2}$

Let $p_{t}(i)$ denote the price of good $i$. Then the consumption-based price indices for different consumption baskets in country $\mathrm{H}$ are given by:

$$
\begin{aligned}
\left(P_{t}^{\mathrm{N}}\right)^{\rho /(\rho-1)} & =\int_{0}^{i_{t}^{*}}\left(\frac{1}{i_{t}^{*}}\right) p_{t}(i)^{\rho /(\rho-1)} d i, & & i \in I^{\mathrm{N}} \\
\left(P_{t}^{\mathrm{H}}\right)^{\rho /(\rho-1)} & =\int_{i_{t}^{*}}^{1}\left(\frac{1}{1-i_{t}^{*}}\right) p_{t}(i)^{\rho /(\rho-1)} d i, & & i \in I^{\mathrm{T}} \\
\left(P_{t}^{\mathrm{F}}\right)^{\rho /(\rho-1)} & =\int_{1}^{2-\hat{\imath}_{t}^{*}}\left(\frac{1}{1-\hat{\imath}_{t}^{*}}\right)\left(p_{t}^{*}(i)\right)^{\rho /(\rho-1)} d i . & & i \in I^{\mathrm{T}}
\end{aligned}
$$

Households in each country finance their consumption expenditures with wage income and profits, $\Pi_{t}$, received from domestic firms. Households also have access to international borrowing and lending at interest rate $R_{t}$. We assume that bonds are denominated in units of internationally tradable goods produced by country $\mathrm{H}^{3} \mathrm{As}$ a result, asset markets in our model are incomplete.

The period- $t$ budget constraint of households living in country H can be written as

$$
P_{t}^{\mathrm{H}} C_{t}^{\mathrm{H}}+P_{t}^{\mathrm{F}} C_{t}^{\mathrm{F}}+P_{t}^{\mathrm{N}} C_{t}^{\mathrm{N}}+\frac{1}{R_{t}} P_{t}^{\mathrm{H}} B_{t} \leq P_{t}^{\mathrm{H}} B_{t-1}+\left(L_{t}^{\mathrm{T}}+L_{t}^{\mathrm{N}}+f_{x}\left(1-i_{t}^{*}\right)\right) w_{t}+\Pi_{t},
$$

where $B_{t}$ denotes period- $t$ holdings of the international bond, $P_{t}^{\chi}$ is the $\mathrm{H}$ country price of internationally traded goods produced in country $\chi$, with $\chi=\{\mathrm{H}, \mathrm{F}\}$, and $L_{t}^{\mathrm{T}}, L_{t}^{\mathrm{N}}$ denote aggregate labor employed in the production of internationally tradable

\footnotetext{
${ }^{2}$ In the numerical results we check the robustness of our findings when the "love of variety" effect is incorporated in the calculation of consumption.

${ }^{3}$ The denomination of the bond does not influence our results.
} 
and non-tradable goods, respectively. The term $f_{x}\left(1-i_{t}^{*}\right) w_{t}$ denotes the wage payments received by domestic labor that was hired by the domestic firms to cover the fixed cost of exporting, $f_{x}$. We discuss this issue in detail below.

Using the household's first-order conditions, we can now define the household demand for each individual good $i$ belonging to the different consumption baskets as

$$
\begin{aligned}
c_{t}(i)=\frac{1}{i_{t}^{*}}\left(p_{t}(i) / P_{t}^{\mathrm{N}}\right)^{1 /(\rho-1)} C_{t}^{\mathrm{N}}, & & i \in I^{\mathrm{N}} \\
c_{t}(i)=\frac{1}{1-i_{t}^{*}}\left(p_{t}(i) / P_{t}^{\mathrm{H}}\right)^{1 /(\rho-1)} C_{t}^{\mathrm{H}}, & & i \in I^{\mathrm{T}} \\
c_{t}^{*}(i)=\frac{1}{1-\hat{\imath}_{t}^{*}}\left(p_{t}^{*}(i) / P_{t}^{\mathrm{F}}\right)^{1 /(\rho-1)} C_{t}^{\mathrm{F}}, & & i \in I^{\mathrm{T}}
\end{aligned}
$$

Note here, that the terms with $i_{t}^{*}$ appear in the expressions above, as we account for the fact that the set of varieties over which aggregates are defined can expand or contract.

Preferences of $\mathrm{F}$ households are similarly defined in terms of the tradable consumption basket, $\hat{C}_{t}^{\mathrm{T}}$, and a nontradable consumption basket, $\hat{C}_{t}^{\mathrm{N}}$. The tradable consumption basket in F country is defined symmetrically in terms of $\mathrm{H}$ tradables, $\hat{C}_{t}^{\mathrm{H}}$, and F tradables, $\hat{C}_{t}^{\mathrm{F}}$, as

$$
\hat{C}_{t}^{\mathrm{T}}=\left[\hat{\lambda}_{\mathrm{H}}\left(\hat{\imath}_{t}^{*}\right)^{1-\rho}\left(\hat{C}_{t}^{\mathrm{H}}\right)^{\rho}+\hat{\lambda}_{\mathrm{F}}\left(\hat{\imath}_{t}^{*}\right)^{1-\rho}\left(\hat{C}_{t}^{\mathrm{F}}\right)^{\rho}\right]^{\frac{1}{\rho}}
$$

Here $\hat{\imath}_{t}^{*}$ denotes the endogenous time- $t$ share of goods that are non-traded in country F. Households in the F country face the budget constraint:

$$
\hat{P}_{t}^{\mathrm{H}} \hat{C}_{t}^{\mathrm{H}}+\hat{P}_{t}^{\mathrm{F}} \hat{C}_{t}^{\mathrm{F}}+\hat{P}_{t}^{\mathrm{N}} \hat{C}_{t}^{\mathrm{N}}+\frac{1}{R_{t}} P_{t}^{\mathrm{H}} \hat{B}_{t} \leq P_{t}^{\mathrm{H}} \hat{B}_{t-1}+\left(\hat{L}_{t}^{\mathrm{T}}+\hat{L}_{t}^{\mathrm{N}}+f_{x}\left(1-\hat{\imath}_{t}^{*}\right)\right) \hat{w}_{t}+\hat{\Pi}_{t},
$$

where $\hat{B}_{t}$ denotes the bond holdings of $\mathrm{F}$ households. As noted previously, goods produced in country $\mathrm{H}$ are set as numeraire.

\subsection{Firms}

Each country specializes in the production of a continuum of goods, indexed by $i \in$ $[0,1]$. Each differentiated good $i$ is produced using constant returns to scale technology in just one input, labor, $l_{t}(i)$ :

$$
y_{t}(i)=X_{t} A(i) l_{t}(i)
$$


Here $X_{t}$ is the total factor productivity (TFP), and $A(i)$ is the good/firm-specific productivity. Productivity differences across firms give rise to firm heterogeneity. Firms can sell their output in two markets: in the domestic (national) market and abroad (international market). ${ }^{4}$

We define the 'nontraded' (N) sector as a sector comprising of firms that sell their goods only on the domestic market, while all firms that also sell on the international market, we define to comprise 'traded' ( $\mathrm{T}$ ) sector. These are the goods that form the corresponding consumption baskets of the households. We assume that TFP is sector-specific and affects all firms who choose to locate in that sector equally.

Exporting to a foreign country is costly. In order to export, it is necessary for a firm to incur a fixed cost, denoted by $f_{x}$;. In addition, there are 'iceberg' transportation costs, $\tau_{I}$. As in Ghironi and Melitz (2005) and Bergin and Glick (2005), we assume that firms hire domestic labor to cover the fixed costs of exporting. Transportation costs are common to all producers.

Differences in productivities also imply different unit costs of production across firms. In particular, if, as before, we let $w_{t}$ denote the wage rate in country $\mathrm{H}$ measured in units of a numeraire good, then $w_{t} / X_{t} A(i)$ represents such unit costs in country $\mathrm{H}$. Further, in each destination market, a firm faces a constant elasticity of substitution (CES) demand function, which we derived in equations (3.3). For instance, when selling in the domestic market in country $\mathrm{H}$, firm $i$ faces demand function given by $c_{t}(i)$, while $\hat{c}_{t}(i)$ denotes the country F's demand for good $i$. When making a decision of which market to service, the firm decomposes its profits into parts earned from national sales and potential international sales. In particular, these components for a firm $i$ operating in country $\mathrm{H}$ can be written as:

(i) profits from national sales:

$$
\pi_{t}(i)=p_{t}(i) c_{t}(i)-\frac{w_{t}}{X_{t} A(i)} c_{t}(i), \quad i \in I^{\mathrm{N}}
$$

(ii) profits from international sales:

$$
\hat{\pi}_{t}(i)=\left\{\begin{array}{ll}
\hat{p}_{t}(i) \hat{c}_{t}(i)-\frac{w_{t}}{X_{t} A(i)} \frac{1}{1-\tau_{I}} \hat{c}_{t}(i)-f_{x} w_{t}, & \text { if firm exports } \\
0, & \text { otherwise }
\end{array} .\right.
$$

\footnotetext{
${ }^{4}$ In our setup, it will be the case that a firm that decides to export internationally, will also sell its products in the domestic market.
} 
In this setup, the maximization problem of a firm $i$ operating in country $\mathrm{H}$ yields a mark-up pricing rule. In particular, for goods sold on the domestic markets, prices are

$$
p_{t}(i)=\frac{1}{\rho} \frac{w_{t}}{X_{t} A(i)} \quad i \in I^{\mathrm{N}} .
$$

Prices for goods sold in the international market are

$$
\hat{p}_{t}=\frac{1}{\rho} \frac{w_{t}}{X_{t} A(i)} \frac{1}{1-\tau_{I}} \quad i \in I^{\mathrm{T}}
$$

Here $\frac{1}{\rho}$ is constant markup, linked to the elasticity of substitution across different varieties of traded and nontraded goods. Due to the fixed costs of exporting, firms with lower productivity levels will choose to sell in the domestic market. When making this decision, a firm computes potential profits from export sales after accounting for the fixed costs of exporting. A firm will export if and only if these profits are nonnegative, that is

$$
\hat{p}_{t}(i) \hat{c}_{t}(i)-\frac{w_{t}}{X_{t} A(i)} \frac{1}{1-\tau_{I}} \hat{c}_{t}(i)-f_{x} w_{t} \geq 0 \quad i \in I^{\mathrm{T}} .
$$

A firm for which $\hat{\pi}_{t}(i)=0$ will pin down the threshold index $i_{t}^{*}$ of the marginal firm that will export. In particular, let $A\left(i^{*}\right) \equiv \inf \left\{A: \hat{\pi}_{t}(i)>0\right\}$ be a productivity cut-off level. Then all firms with productivities below with cutoff, $A(i)<A\left(i^{*}\right)$, will only sell in country $\mathrm{H}$, while the firms with $A(i)>A\left(i^{*}\right)$ will also be able to sell in country F. Firms operating in country $\mathrm{F}$ face a similar problem.

Following Melitz (2003) and Bergin and Glick (2005), we define "average" productivity levels - average $A$ - for firms producing different categories of goods in country $\mathrm{H}:$

$$
\begin{aligned}
\tilde{A}_{\mathrm{N}}^{\frac{\beta}{1-\beta}} & =\frac{1}{i^{*}} \int_{0}^{i^{*}} A(i)^{\frac{\rho}{1-\rho}} d i \\
\tilde{A}_{\mathrm{T}}^{\frac{\rho}{1-\rho}} & =\frac{1}{1-i^{*}} \int_{i^{*}}^{1} A(i)^{\frac{\rho}{1-\rho}} d i \\
\tilde{A}^{\frac{\phi}{1-\phi}} & =\int_{0}^{1} A(i)^{\frac{\phi}{1-\phi}} d i .
\end{aligned}
$$

Our focus is on aggregate dynamics, and as shown in Melitz (2003), the average productivities are sufficient to characterize these dynamics. We can now define average 
goods prices in terms of these productivity averages. In particular, prices of goods sold on the domestic market in country $\mathrm{H}$ are given by:

$$
P_{t}^{\mathrm{N}}=\frac{1}{\rho} \frac{w_{t}}{X_{t} \tilde{A}_{\mathrm{N}}}, \quad P_{t}^{\mathrm{H}}=\frac{1}{\rho} \frac{w_{t}}{X_{t} \tilde{A}_{\mathrm{T}}} .
$$

Here $P_{t}^{\mathrm{N}}, P_{t}^{\mathrm{H}}$ denote prices of internationally-nontraded and internationally-traded goods, respectively, in country H. Prices of goods that originated in country H and are sold in the international markets are given by

$$
\hat{P}_{t}^{\mathrm{H}}=\frac{1}{\rho} \frac{w_{t}}{X_{t} \tilde{A}_{\mathrm{T}}} \frac{1}{1-\tau_{I}} .
$$

An analogous set of prices applies to the F country.

Profits received by domestic firms in country $\mathrm{H}$ are given as the sum of profits received by domestic firms selling in two different markets:

$$
\Pi_{t}=\left.\int_{0}^{i_{t}^{*}} \pi_{t}(i) d i\right|_{i \in I^{N}}+\left.\int_{i_{t}^{*}}^{1} \pi_{t}(i) d i\right|_{i \in I^{\mathrm{T}}}+\left.\int_{i_{t}^{*}}^{1} \hat{\pi}_{t}(i) d i\right|_{i \in I^{\mathrm{T}}} .
$$

Profits received by firms in country F are defined analogously.

\subsection{Equilibrium}

The first-order conditions for $\mathrm{H}$ households are given by

$$
\begin{aligned}
& \frac{\partial U_{t} / \partial C_{t}^{\mathrm{F}}}{\partial U_{t} / \partial C_{t}^{\mathrm{H}}}=\frac{P_{t}^{\mathrm{F}}}{P_{t}^{\mathrm{H}}}, \\
& \frac{\partial U_{t} / \partial C_{t}^{\mathrm{N}}}{\partial U_{t} / \partial C_{t}^{\mathrm{H}}}=\frac{P_{t}^{\mathrm{N}}}{P_{t}^{\mathrm{H}}} .
\end{aligned}
$$

These equations define the relative prices of $\mathrm{F}$ traded goods, and $\mathrm{H}$ nontraded goods in terms of $\mathrm{H}$ international tradables as ratios of their respective marginal utilities to the marginal utility of $\mathrm{H}$ tradables. In the bond economy, the first-order conditions also include

$$
P_{t}^{\mathrm{H}} \partial U_{t} / \partial C_{t}^{\mathrm{H}}=\beta R_{t} \mathbb{E}_{t} P_{t+1}^{\mathrm{H}} \partial U_{t} / \partial C_{t+1}^{\mathrm{H}},
$$

which is the standard pricing equations for the bond. The first-order conditions for F households are symmetric. 
In equilibrium, households and firm decisions must also be consistent with the market clearing conditions. The market clearing conditions in the nontraded goods sector are

$$
c_{t}(i)=y_{t}(i) \quad \text { and } \quad \hat{c}_{t}(i)=\hat{y}_{t}(i), \quad i \in I^{\mathrm{N}}
$$

In equilibrium, the world demand for each internationally-traded good must be equal to its corresponding supply:

$$
\begin{aligned}
c_{t}(i)+\hat{c}_{t}(i) \frac{1}{1-\tau_{I}} & =y_{t}(i), \quad i \in I^{\mathrm{T}} \\
\hat{c}_{t}^{*}(i)+c_{t}^{*}(i) \frac{1}{1-\tau_{I}} & =\hat{y}_{t}(i), \quad i \in I^{\mathrm{T}} .
\end{aligned}
$$

Here $\hat{c}\left[c^{*}\right], i \in \mathrm{T}$ is consumption demand for internationally-traded goods produced in $\mathrm{H}[\mathrm{F}]$ country and sold in the $\mathrm{F}[\mathrm{H}]$ country, as defined before.

Labor market clearing in each region within country $\mathrm{H}$ requires

$$
\begin{aligned}
& \int_{0}^{i_{t}^{*}} l_{t}(i) d i+\int_{i_{t}^{*}}^{1} l_{t}(i) d i+f_{x}\left(1-i_{t}^{*}\right)=L, \\
& \int_{0}^{\hat{\imath}_{t}^{*}} \hat{l}_{t}(i) d i+\int_{\hat{\imath}_{t}^{*}}^{1} \hat{l}_{t}(i) d i+f_{x}\left(1-\hat{\imath}_{t}^{*}\right)=\hat{L},
\end{aligned}
$$

where $L(\hat{L})$ is the exogenously given labor supply in country $\mathrm{H}[\mathrm{F}]$.

We also require an asset market clearing condition. We assume that bonds are in zero net supply, so that bond market clearing condition is $B_{t}+\hat{B}_{t}=0$.

An equilibrium in this economy consists of a sequence of goods prices $\left\{P_{t}^{\mathrm{H}}, P_{t}^{\mathrm{F}}, \hat{P}_{t}^{\mathrm{H}}\right.$, $\left.\hat{P}_{t}^{\mathrm{F}}, P_{t}^{\mathrm{N}}, \hat{P}_{t}^{\mathrm{N}}\right\}$ and an interest rate $R_{t}$, such that households in both countries make their consumption and bond allocation decisions optimally, taking prices as given; firms in both countries make their profit maximizing decisions; and all markets clear.

\subsection{Variables of interest}

In our economy there is a sequence of price indices that comprise regional and international real exchange rates. To simplify the notation, we omit explicit references to $i^{*}$ in the consumption weights, $\lambda_{\mathrm{H}}, \lambda_{\mathrm{F}}, \lambda_{\mathrm{N}}, \lambda_{\mathrm{T}}$.

Recall that $P_{t}^{\mathrm{T}}$ denotes the price of the aggregate internationally traded consumption basket in country $\mathrm{H}$. It is composed of prices of internationally traded goods in 
country H:

$$
P_{t}^{\mathrm{T}}=\left[\lambda_{\mathrm{H}}\left(i_{t}^{*}\right)\left(P_{t}^{\mathrm{H}}\right)^{\frac{\rho}{\rho-1}}+\lambda_{\mathrm{F}}\left(i_{t}^{*}\right)\left(P_{t}^{\mathrm{F}}\right)^{\frac{\rho}{\rho-1}}\right]^{\frac{\rho-1}{\rho}} .
$$

The aggregate price index in country $\mathrm{H}$, therefore, is given by

$$
P_{t}=\left[\lambda_{\mathrm{T}}\left(i_{t}^{*}\right)\left(P_{t}^{\mathrm{T}}\right)^{\frac{\phi}{\phi-1}}+\lambda_{\mathrm{N}}\left(i_{t}^{*}\right)\left(P_{t}^{\mathrm{N}}\right)^{\frac{\phi}{\phi-1}}\right]^{\frac{\phi-1}{\phi}}
$$

The price indices in the foreign country are symmetrically defined. The price of aggregate internationally traded consumption basket in country $\mathrm{F}$ is given by

$$
\hat{P}_{t}^{\mathrm{T}}=\left[\hat{\lambda}_{\mathrm{H}}\left(\hat{\imath}_{t}^{*}\right)\left(\hat{P}_{t}^{\mathrm{H}}\right)^{\frac{\rho}{\rho-1}}+\hat{\lambda}_{\mathrm{F}}\left(\hat{\imath}_{t}^{*}\right)\left(\hat{P}_{t}^{\mathrm{F}}\right)^{\frac{\rho}{\rho-1}}\right]^{\frac{\rho-1}{\rho}}
$$

while the aggregate price index in country $\mathrm{F}$ is

$$
\hat{P}_{t}=\left[\hat{\lambda}_{\mathrm{T}}\left(\hat{\imath}_{t}^{*}\right)\left(\hat{P}_{t}^{\mathrm{T}}\right)^{\frac{\phi}{\phi-1}}+\hat{\lambda}_{\mathrm{N}}\left(\hat{\imath}_{t}^{*}\right)\left(\hat{P}_{t}^{\mathrm{N}}\right)^{\frac{\phi}{\phi-1}}\right]^{\frac{\phi-1}{\phi}}
$$

The international real exchange rate in our model, $R E R_{t}$, is given by the ratio of $\mathrm{F}$ to $\mathrm{H}$ aggregate price indices:

$$
R E R_{t}=\frac{\hat{P}_{t}}{P_{t}}
$$

The terms-of-trade in the model are defined as a relative price of foreign to domestic internationally-traded goods and are given by $T O T_{t}=P_{t}^{\mathrm{F}} / P_{t}^{\mathrm{H}}$.

The nontraded output share in the domestic economy is computed as $P_{t}^{\mathrm{N}} Y_{t}^{\mathrm{N}} / P_{t} Y_{t}$, where $Y_{t}^{\mathrm{N}}$ and $Y_{t}$ are, respectively, real output produced in the nontraded sector, and on aggregate in the $\mathrm{H}$ economy.

\section{Parameter values and computations}

Parameter values for the calibration of our benchmark model are summarized in Table 3. We consider the world economy as consisting of two symmetric countries, roughly matching the properties of the US economy in annual data. Most of the preference parameter values are standard in the literature and, in particular, follow closely those adopted by Stockman and Tesar (1995). In particular, $\delta$ is set to 0.96 to obtain the steady-state real interest rate of $4 \%$ per annum. The coefficient of relative risk 
aversion, $\omega$, is set to 2 . The values for substitution elasticities are chosen as follows. First, the value for $\phi$ is set, following Mendoza (1995), to obtain the elasticity of substitution between tradable and nontradable consumption equal to 0.74. Second, the elasticity of substitution between $\mathrm{H}$ and $\mathrm{F}$ traded goods is set to equal 6 to obtain a $20 \%$ mark-up of price over marginal costs, a value commonly used in the literature (Obstfeld and Rogoff, 2000).

Table 3: Benchmark Model Parameters

\begin{tabular}{llc}
\hline \hline & & \\
\hline \hline PREFERENCES & $\delta$ & 0.96 \\
Subjective discount factor & $\omega$ & 2 \\
Risk-aversion & $\lambda^{\mathrm{N}}$ & 0.55 \\
Share of nontraded goods & & \\
$\quad \begin{array}{l}\text { Elasticity of substitution b/n } \\
\quad \text { traded and nontraded goods }\end{array}$ & $1 /(1-\phi)$ & 0.74 \\
$\quad$ H and F traded goods & $1 /(1-\rho)$ & 6 \\
\hline PRODUCTIVITY & $a_{i i}^{\mathrm{H}}=a_{i i}^{\mathrm{F}}$ & 0.9 \\
Persistence of traded shocks & $a_{i i}^{\mathrm{N}}$ & 0.9 \\
$\begin{array}{l}\text { Persistence of nontraded shocks } \\
\text { Volatility of }\end{array}$ & $\Omega_{e}^{\mathrm{H}}=\Omega_{e}^{\mathrm{F}}$ & 0.01 \\
$\quad$ traded innovations (std.dev.) & & 0.005 \\
$\quad$ nontraded innovations (std.dev.) & & \\
\hline \hline
\end{tabular}

We parameterize the fixed cost of the exporting parameter, $f_{x}$, in both countries to obtain the share of nontradables in aggregate consumption expenditure, $\lambda_{\mathrm{N}}$ and $\hat{\lambda}_{\mathrm{N}}$, equal to 0.55 in the steady state. This number is calculated using OECD STructural ANalysis (STAN) database. ${ }^{5}$ We set the shares of home goods in the internationallytraded consumption basket in both countries, $\lambda_{\mathrm{H}}$ and $\hat{\lambda}_{\mathrm{F}}$, to 0.5 in the steady state, so that there is no consumption home bias built in exogenously in the model. Instead we calibrate the international iceberg transportation costs to match the share of international imports to be equal to $10 \%$ of output in the steady state.

The available estimates for sectoral productivity processes in the literature are very dissimilar (see, for instance, Corsetti et al., 2008; Benigno and Thoenissen, 2008; Tesar, 1993; Stockman and Tesar, 1995), thus we assume independent pro-

\footnotetext{
${ }^{5}$ These numbers are similar to the estimates in the literature. For instance, Corsetti et al. (2008) and Dotsey and Duarte (2008) use $\lambda_{\mathrm{N}}=0.55$, Stockman and Tesar (1995) report $\lambda_{\mathrm{N}}$ close to 0.5; Pesenti and van Wincoop (2002) also argue that 0.5 of consumers budget is allocated to nontradables; Benigno and Thoenissen (2008) assume $\lambda_{\mathrm{N}}=0.45$.
} 
ductivity processes across sectors, across regions and across countries. Each of the productivity processes follows an $\mathrm{AR}(1)$ process. The $\mathrm{AR}(1)$ coefficients are all set to 0.9. Innovations to internationally traded productivity have standard deviation of 0.01 , while innovations to internationally nontraded productivity are half that size. These numbers are consistent with the empirical findings that traded productivity exhibits more volatility than nontraded productivity (see Dotsey and Duarte (2008)). We parameterize good/firm-specific productivity following Bergin and Glick (2005) as $A_{i}=\psi(1+i)$, with $\psi=1$.

The model is solved by linearizing the system of equilibrium conditions and solving the resulting system of linear difference equations. To make our bond economy stationary, we introduce small quadratic costs on bond holdings. We study the properties of the model's equilibrium by simulating it over 100 periods. The statistics reported in the next section are derived from 200 simulations.

\section{Results}

Table 4 summarizes the results from model simulations. We start by characterizing the properties of a production economy with no firm heterogeneity due to firm-specific productivity (panels (i) in the Table). This simplification eliminates the endogenous non-tradability feature in our model and reduces the setting to a standard international business cycle economy with a representative firm in each country. Then we allow for firm heterogeneity and consider a production economy with endogenous tradability (panels (ii) of the Table). The statistics for the U.S. during 1970-2007 period are presented in the row labelled "U.S. Data". ${ }^{6}$

Without endogenous tradability, our model has been used extensively in the literature to study international business cycles, terms of trade and real exchange rate movements (see Tesar, 1993; Corsetti et al., 2008; Benigno and Thoenissen, 2008). The international business cycle properties of this version of our model, therefore, are standard. Some of the usual shortcomings of international business cycles models are present in our case as well. In particular, while the model matches well the majority of volatilities of macro aggregates, it considerably underpredicts the volatilities of

\footnotetext{
${ }^{6}$ To compute all cross-country or international correlations we used the data for the U.S. and the rest of the world during 1973-2007 period. The latter was constructed as a weighted aggregate of Canada, Japan and 19 European economies. See Appendix A for details on data sources and calculations.
} 
international relative prices. Given our focus on the nontraded sector share we also report the volatility of the nontraded share relative to the volatility of GDP. This number is 0.4 - well below its value of 1.05 we estimated in the OECD data.

In terms of correlations, the model does well at matching the co-movements of consumption, traded sector employment, imports and net exports with output, but predicts counterfactual co-movements for international relative prices and exports with output. For the new variable of interest - the nontraded output share - the model predicts it to be strongly countercyclical, in excess of what we measured in the data. Finally, when it comes to cross-country correlations, the model predicts positive cross-country correlation for consumption and output, consistent with the data; but negative for labor inputs, in contrast to the data.

Models similar to ours, with no endogenous tradability, have also been used extensively to study the degree of international risk-sharing. Efficient risk sharing in this model implies that expected relative consumption growth should co-move positively with expected real exchange rate changes. Numerous studies have noted that this positive co-movement is absent in international data. This discrepancy has been labeled the 'Backus-Smith-Kollman' puzzle, (after Backus and Smith (1993) and Kollmann (1995)). We compute a similar correlation in our model and find it to be positive, as earlier studies have documented. This correlation is positive and high when we consider both levels and growth rates of the two variables ( 0.3 in levels and in growth rates). In contrast, in the OECD data this correlation is negative, both in levels and in growth rates.

Overall, focusing just on the properties of the nontraded output share, the model predicts too little volatility in that share relative to the data, and too much negative co-movement with output relative to the data.

Next, we consider a version of the model with firm heterogeneity and endogenous tradability. The results are summarized in panels (ii) of Table 4. This extended model performs similarly to the version with a representative firm for a majority of macroeconomic moments. However, it significantly improves the fit to the data in several key dimensions. First, it generates more volatile labor input in both the traded and nontraded sectors, almost matching the numbers found in the data. Second, the extended model predicts nontraded output share whose properties closely line up with the data. In particular, it raises the volatility of nontraded share to 0.89 (relative to 1.05 in the data), and raises its co-movement with output to -0.28 , thus replicating it 
Table 4: Volatilities and correlations

\begin{tabular}{|c|c|c|c|c|c|c|c|c|c|}
\hline \multirow[t]{2}{*}{ Volatilities } & \multicolumn{9}{|c|}{$\% \frac{\% \text { std dev }}{\text { std dev of } y}$} \\
\hline & $c$ & $l^{\mathrm{T}}$ & $l^{\mathrm{N}}$ & tot & rer & $e x$ & $i m$ & $n x$ & Nshare \\
\hline U.S. Data ${ }^{7}$ & 0.62 & 0.88 & 0.88 & 1.77 & 2.38 & 2.64 & 3.34 & 0.50 & 1.05 \\
\hline (i) no endogenous tradability & 0.79 & 0.48 & 0.40 & 0.70 & 1.28 & 2.94 & 2.92 & 0.51 & 0.40 \\
\hline (ii) with endogenous tradability & 0.82 & 1.06 & 0.90 & 0.62 & 1.38 & 2.84 & 2.83 & 0.53 & 0.89 \\
\hline Co-movements & $c, y$ & $l^{\mathrm{T}}, y$ & $l^{\mathrm{N}}, y$ & tot, $y$ & rer, $y$ & $e x, y$ & $i m, y$ & $n x, y$ & Nshare, $y$ \\
\hline U.S. Data & 0.82 & 0.69 & 0.69 & -0.16 & 0.16 & 0.42 & 0.82 & -0.37 & -0.28 \\
\hline (i) no endogenous tradability & 0.89 & 0.41 & -0.41 & 0.61 & -0.19 & -0.30 & 0.83 & -0.62 & -0.41 \\
\hline (ii) with endogenous tradability & 0.89 & 0.27 & -0.27 & 0.56 & -0.36 & -0.22 & 0.83 & -0.57 & -0.28 \\
\hline Cross-country correlations & $y, \hat{y}$ & $c, \hat{c}$ & $l^{\mathrm{T}}, \hat{l}^{\mathrm{T}}$ & $l^{\mathrm{N}}, \hat{l}^{\mathrm{N}}$ & $c-$ & rer & $\Delta(c$ &,$\Delta r e r$ & \\
\hline U.S. Data & 0.58 & 0.43 & 0.70 & 0.70 & & & & & \\
\hline (i) no endogenous tradability & 0.07 & 0.70 & -0.57 & -0.57 & & & & & \\
\hline (ii) with endogenous tradability & 0.25 & 0.83 & -0.62 & -0.62 & & & & & \\
\hline
\end{tabular}

in the data exactly. Third, an important improvement in the model with endogenous tradability is the fact that it predicts significantly lower degree of international risksharing relative to the model with a representative firm. In particular, the correlation between relative consumption and the real exchange rate in this version of the model is 0.03 , in both levels and growth rates - much closer to the values observed in the data. This correlation, however, remains positive, implying that endogenous nontradability per se is not sufficient to completely resolve the Backus-Smith-Kollman puzzle. $^{8}$

\section{Discussion}

To understand the results above it is useful to consider how our model economy responds to various shocks. Thus we present the impulse responses of various macroeconomic aggregates and prices following sectoral productivity shocks in the home country. It also proves useful to decompose the real exchange rate into its components. In particular, in Appendix A.3 we show that the log international real exchange

\footnotetext{
${ }^{8}$ The model with endogenous tradability implies that the measure of varieties available for consumption is changing over time. To account for this, we adjust the measurement of consumption to account for expanding varieties and re-compute the correlation between this adjusted measure of consumption and the real exchange rate. We find that the results remain relatively unchanged. In particular, the correlation is 0.04 in levels and 0.03 in growth rates.
} 
rate (in deviation from the steady state), can be expressed as

$$
r e r_{t}=\left(\lambda_{\mathrm{H}}-\lambda_{\mathrm{F}}\left(\frac{1}{1-\tau_{I}}\right)^{\frac{\rho}{\rho-1}}\right) \kappa_{1}\left(\hat{p}_{t}^{\mathrm{F}}-p_{t}^{\mathrm{H}}\right)+\hat{\lambda}_{\mathrm{N}} \kappa_{2}\left(\hat{p}_{t}^{\mathrm{N}}-\hat{p}_{t}^{\mathrm{T}}\right)-\lambda_{\mathrm{N}} \kappa_{2}\left(p_{t}^{\mathrm{N}}-p_{t}^{\mathrm{T}}\right)
$$

where lowercase letters denote the log transformations for all variables in deviations from their steady state values (e.g., $p_{t}^{\mathrm{H}} \equiv \ln P_{t}^{\mathrm{H}}-\ln P^{\mathrm{H}}$, etc.); and $\kappa_{1}^{\frac{\rho-1}{\rho}}=\left(\hat{P}^{\mathrm{F}} / P^{\mathrm{T}}\right)$, $\kappa_{2}^{\frac{\phi-1}{\phi}}=\left(\hat{P}^{\mathrm{N}} / \hat{P}\right)=\left(P^{\mathrm{N}} / P\right)$ are coefficients that depend on the steady state values of relative prices.

The expression in (6.16) decomposes the international real exchange rate into two components: (i) a component associated with the international terms of trade movements,

$\left(\lambda_{\mathrm{H}}-\lambda_{\mathrm{F}}\left(\frac{1}{1-\tau_{I}}\right)^{\frac{\rho}{\rho-1}}\right) \kappa_{1}\left(\hat{p}_{t}^{\mathrm{F}}-p_{t}^{\mathrm{H}}\right) ;$, and (ii) a component arising due to variations in the relative prices of internationally-nontraded goods (the last two terms in the expression above). ${ }^{9}$ If there is consumption home bias in households' preferences, $\left(\lambda_{\mathrm{H}}-\lambda_{\mathrm{F}}\left(\frac{1}{1-\tau_{I}}\right)^{\frac{\rho}{\rho-1}}\right)>$ 0 , then the improvements in the terms of trade will be associated with the real exchange rate appreciation. Furthermore, any variations in the relative price of nontraded goods in the two countries will also contribute to real exchange rate movements to the extent of the weight of nontraded consumption in the aggregate consumption basket of the two countries, $\lambda_{N} \kappa_{2}$ and $\hat{\lambda}_{N} \kappa_{2}$.

\subsection{No endogenous tradability}

We begin by discussing the adjustments to sectoral shocks in the simplified version of the model with no firm heterogeneity and endogenous tradability. In the model the productivity shocks can originate in two sectors: internationally traded $(\mathrm{T})$ and internationally nontraded $(\mathrm{N})$.

Figure 2 illustrates the adjustments of key macroeconomic variables to a positive $1 \% \mathrm{~T}$ productivity shock in the $\mathrm{H}$ country. The top panels show impulse responses of $\mathrm{T}, \mathrm{N}$, and aggregate output, as well as the nontraded output share. The bottom figures illustrate the responses of relative consumption, the real exchange rate and its components (from the decomposition in equation (6.16)) to the same shock. In

\footnotetext{
${ }^{9} \mathrm{~A}$ similar decomposition is also derived in Benigno and Thoenissen (2008) in the context of a two-country two-sector model with no iceberg trade costs.
} 
response to a positive $\mathrm{T}$ shock, $\mathrm{H}$ traded output goes up relative to country F's traded output. As a result, $\mathrm{H}$ terms of trade deteriorate, which tends to depreciate the real exchange rate. This effect, however, may be counterbalanced by the movements in the relative prices of nontraded goods. The latter will arise from two sources. The first is due to a standard Balassa-Samuelson effect, where a positive productivity shock in the $\mathrm{T}$ sector will trigger an increase in the real wage, thus driving up relative prices of nontraded goods; the latter adjustment is necessary to prevent all labor from reallocating into the traded sector and out of the nontraded sector. This is a supply side effect and we refer to it as the resource-shifting channel.

The second effect arises from the CES structure of preferences and the desire of households to consume a balanced basket of traded and nontraded different good. Thus, following a productivity improvement in the $\mathrm{T}$ sector, domestic households experience a positive wealth effect, which leads them to increase their demand for nontraded goods, which in turn will drive up their prices. This is the demand-side effect and we refer to it as the demand-composition channel. In our model these two effects dominate the fall in the terms of trade and, as a result, positive productivity shocks in the $\mathrm{T}$ sector are associated with real exchange rate appreciation and an increase in relative consumption. This gives rise to the negative Backus-Smith-Kollman correlation.

What do these adjustments imply for the nontraded output share? An increase in the output of traded goods, combined with the contraction of labor in the nontraded sector lead to a drop in the nontraded output share. This fall is accompanied by a rise in domestic GDP, thus implying that the nontraded share is countercyclical.

Positive shocks that originate in the $\mathrm{N}$ sector have the opposite effect on the real exchange rate. Figure 3 illustrates the adjustments after a $1 \%$ positive shock to N productivity in country $\mathrm{H}$. Such $\mathrm{N}$ sector shocks lead to a fall in the relative price of nontraded goods, thus depreciating the real exchange rate. Given the low elasticity of nontraded demand, this price decline is large. The fall in the relative price of nontraded goods lowers the value marginal product of labor in the nontraded sector, leading to an outflow of workers into the traded sector. Output of traded goods in country $\mathrm{H}$ thus rises relative to the foreign economy. This resource-shifting channel leads to a terms of trade deterioration in the economy experiencing a positive $\mathrm{N}$ productivity shock. This effect is, however, weak. Thus, positive shocks to the N productivity lead to a real exchange rate depreciation and an increase in relative consumption, 
Figure 2: Impulse responses after $1 \%$ positive shock to $\mathrm{T}$ sector productivity in country $\mathrm{H}$

International RER and relative consumption

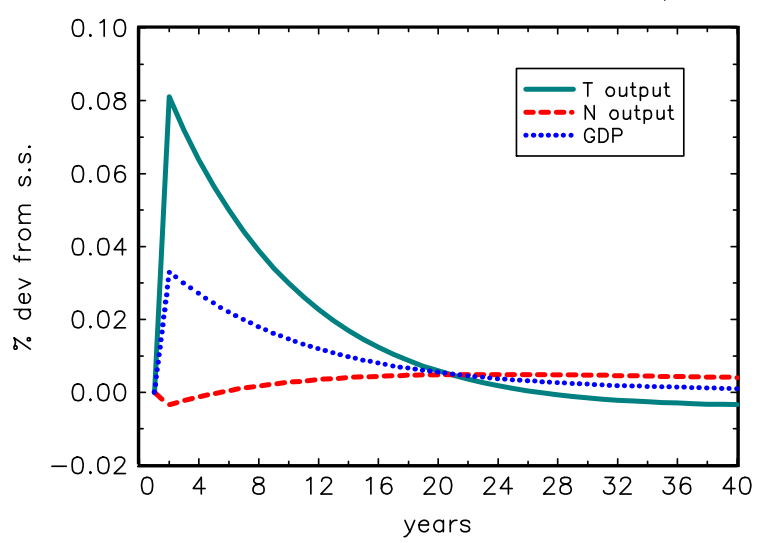

International RER and relative consumption

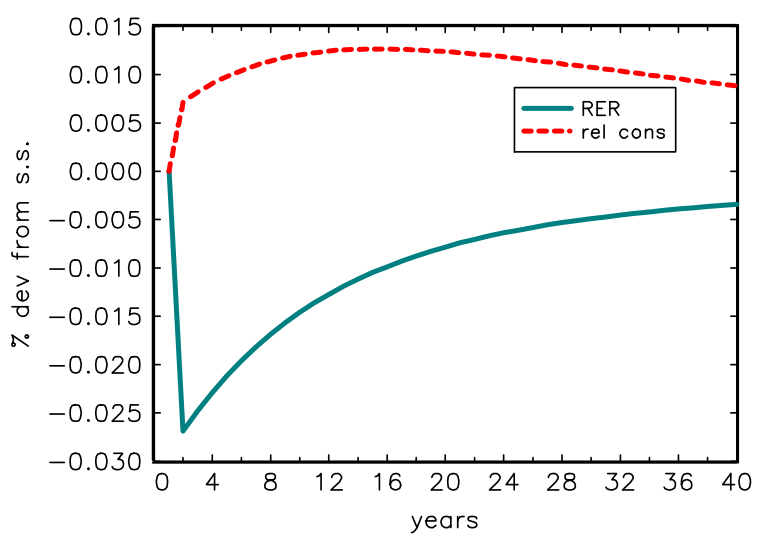

$\mathrm{N}$ output share

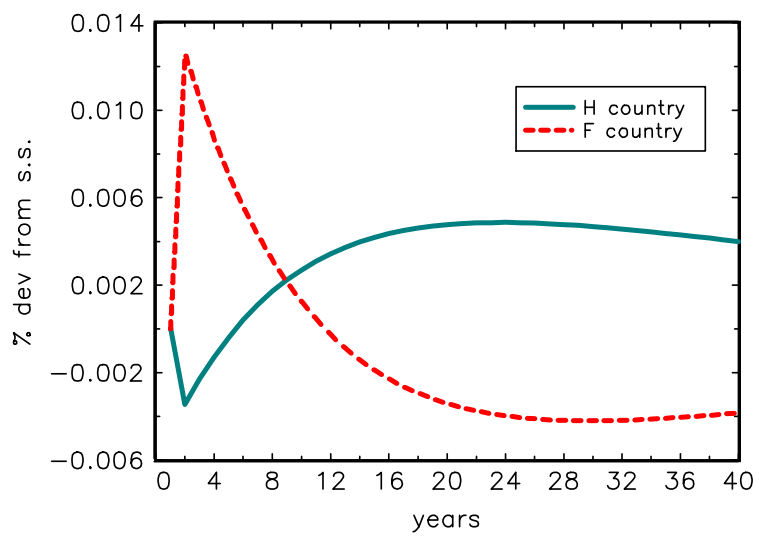

RER components

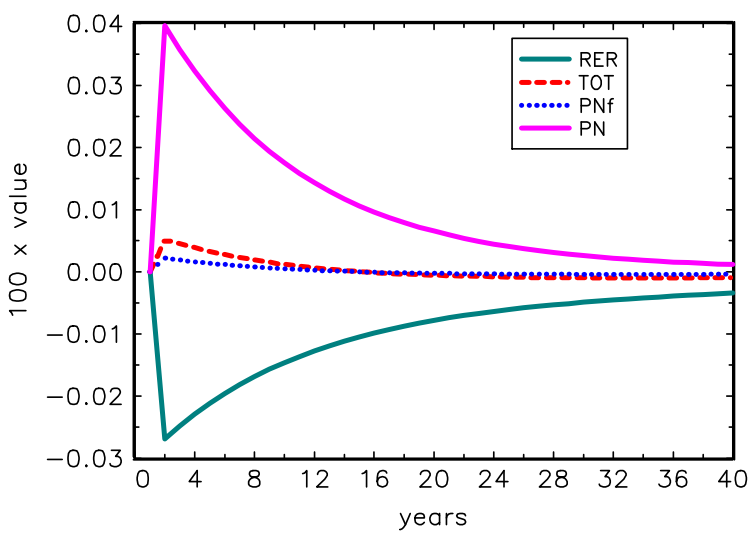

implying a positive correlation between consumption and real exchange rates, and working against the resolution of the Backus-Smith-Kollman puzzle. Quantitatively, we find that nontraded shocks dominate the adjustments of the real exchange rate, thus leading to an overall positive correlation between relative consumption and the real exchange rate in the model. The reason is that in the presence of an international bond, households can smooth out the effects of $\mathrm{T}$ shocks much better than the effects of $\mathrm{N}$ shocks. The effects of the former, therefore, are moderated through bond trade.

The reallocation of workers from the nontraded sector into the traded sector, combined with a large fall in the relative price of nontraded sector output lead to a contraction in the nontraded output share. Thus, the model prediction of countercyclical behavior of nontraded output share remains robust to the origin of productivity shocks 
in the economy.

Figure 3: Impulse responses after $1 \%$ positive shock to $\mathrm{N}$ sector productivity in country $\mathrm{H}$

International RER and relative consumption
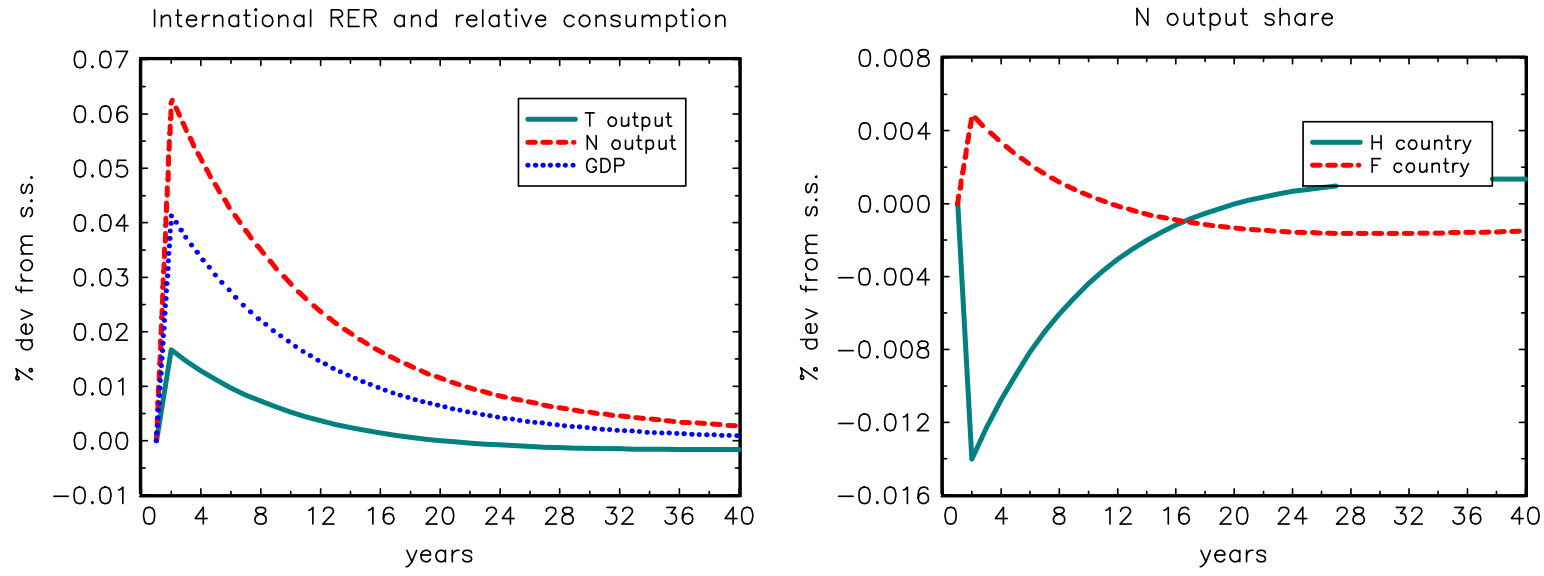

International RER and relative consumption
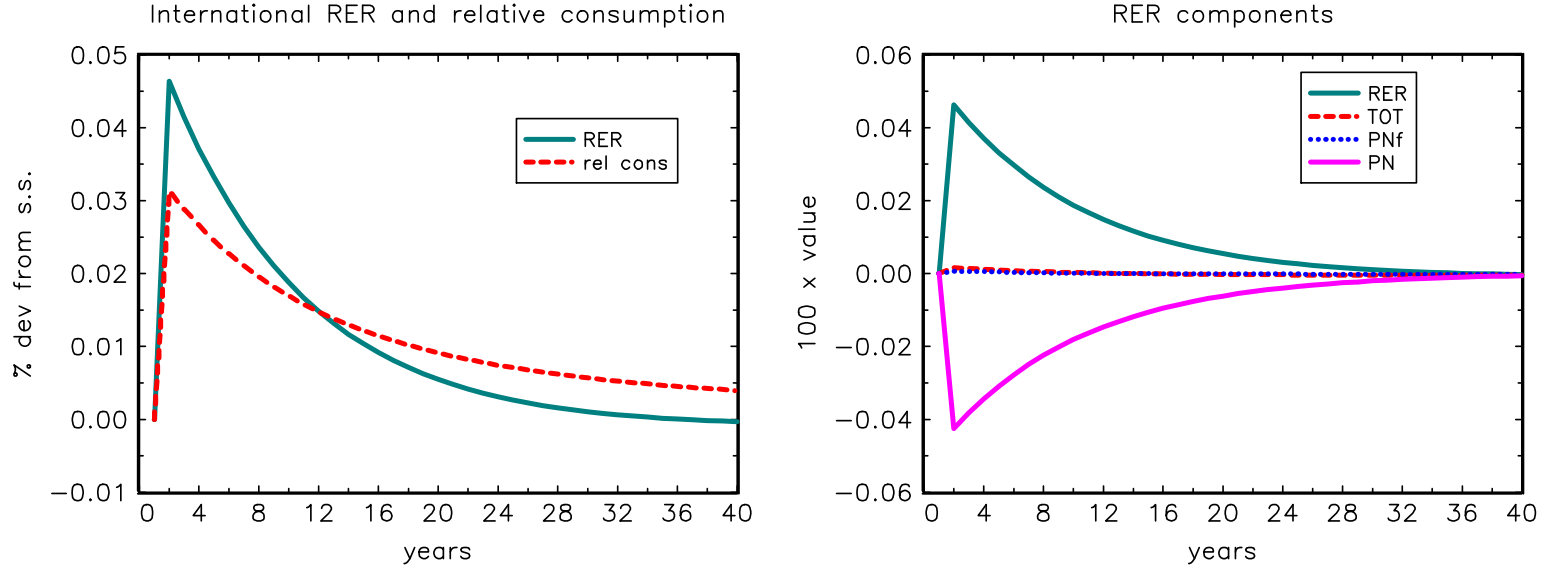

\subsection{With endogenous tradability}

Next, we consider the impulse responses arising in the model with endogenous tradability. Top panel in Figure 4 summarizes the responses of T, N, and aggregate output, as well as $\mathrm{N}$ output share to a $1 \%$ positive shock to T productivity in country $\mathrm{H}$. The bottom panel of Figure 4 does the same for relative consumption, the real exchange rate and its components using the decomposition in equation (6.16). Notice that all responses presented in Figure 4 are qualitatively similar to the responses obtained in the version of the model with no endogenous tradability in Figure 2. The key 
difference between them, however, lies in the magnitudes of the responses. As before, $\mathrm{T}$ sector output and aggregate output rise following the shock, but these increases are much larger with endogenous tradability. Also, $\mathrm{N}$ sector output falls as in the model with no tradability, but does so by a larger amount. The reason behind these amplified adjustments in output is the extensive margin in sectoral reallocation. In the model with no endogenous tradability studied earlier, following a positive shock, labor was reallocating from the nontraded sector into the traded sector. That is, the adjustment on the supply side was taking place at the intensive margin, through the labor employment per firm. With endogenous tradability, the intensive margin is still present. However, it gets amplified by the extensive margin as more firms enter the export market in country $\mathrm{H}$.

In our model firm reallocations closely resemble sectoral movements of labor. Thus, in response to $\mathrm{T}$ productivity improvement, unit production costs in the traded sector decline, providing higher profits to firms operating in that sector and higher potential profits from international sales (higher demand elasticity for traded goods in comparison to demand elasticity for nontraded goods is key for this result). As a result, some less-productive firms that previously serviced the national market only will find it profitable to export. The threshold index $i_{t}^{*}$ that defines the sectoral split will shift to the left to include these less productive producers. The size of the traded sector thus expands, while the size of the nontraded sector contracts. With fewer nontraded goods produced, the relative price of these goods goes up by more, making the real exchange rate appreciate by a larger amount. The extensive margin thus amplifies the adjustments relative to the representative firm economy, making the effects of $\mathrm{T}$ shocks on macro aggregates and relative prices more pronounced.

A similar intuition applies to $\mathrm{N}$ sector productivity shocks. Figure 5 presents impulse responses following a positive $1 \%$ shock to nontraded productivity in home country. As before, this shock is accompanied by an increase in N output and a fall in the relative prices of $\mathrm{N}$ goods. The fall in prices brings down the value marginal product of labor leading to workers moving out of the $\mathrm{N}$ sector and into the $\mathrm{T}$ sector. The fall in the value marginal product of labor also lowers unit costs of production in the traded sector, leading to marginal firms relocating from $\mathrm{N}$ sector into $\mathrm{T}$ sector. Thus, the increase in $\mathrm{N}$ output after a positive productivity shock in that sector is mitigated by both labor and firms moving out of $\mathrm{N}$ sector into $\mathrm{T}$ sector. Quantitatively, however, this effect turns out to be small. The adjustments in the T 
Figure 4: Impulse responses after $1 \%$ positive shock to $\mathrm{T}$ sector productivity in country H: With endogenous tradability

International RER and relative consumption

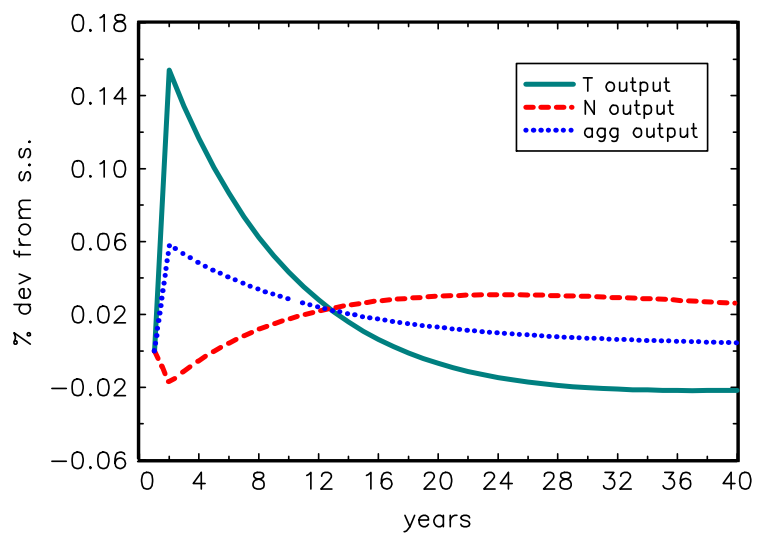

International RER and relative consumption

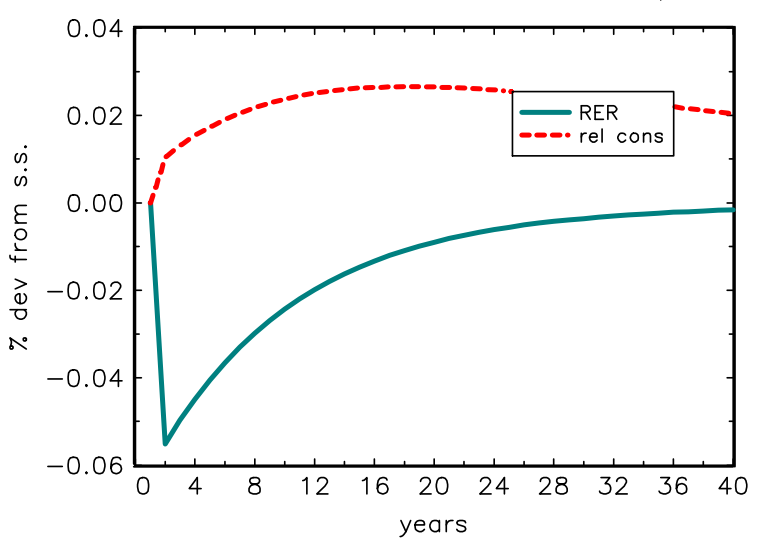

$\mathrm{N}$ output share

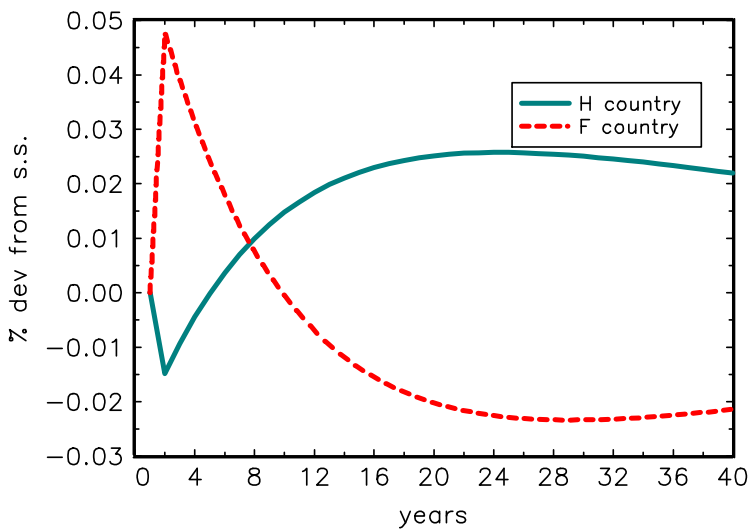

RER components

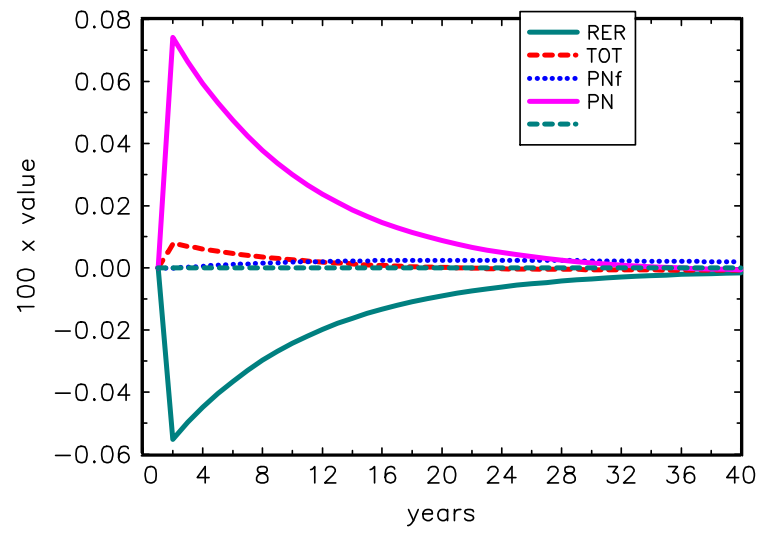

sector are more significant - there the output rises twice the amount it did with no endogenous tradability.

With incomplete markets, this magnifies the positive wealth effects to domestic households, allowing them to raise their consumption further. Thus relative consumption goes up by more in the economy with endogenous tradability. But again, this effect is quantitatively small.

Overall, we find that introducing endogenous tradability increases the responsiveness of the nontraded output share, no matter the sector of productivity change. When productivity in either sector improves it leads to a fall in the share of nontraded goods in the aggregate output. This is due to both workers and firms reallocating away from the $\mathrm{N}$ sector and into the $\mathrm{T}$ sector. These reallocations tend to amplify the 
Figure 5: Impulse responses after $1 \%$ positive shock to $\mathrm{N}$ sector productivity in country H: With endogenous tradability
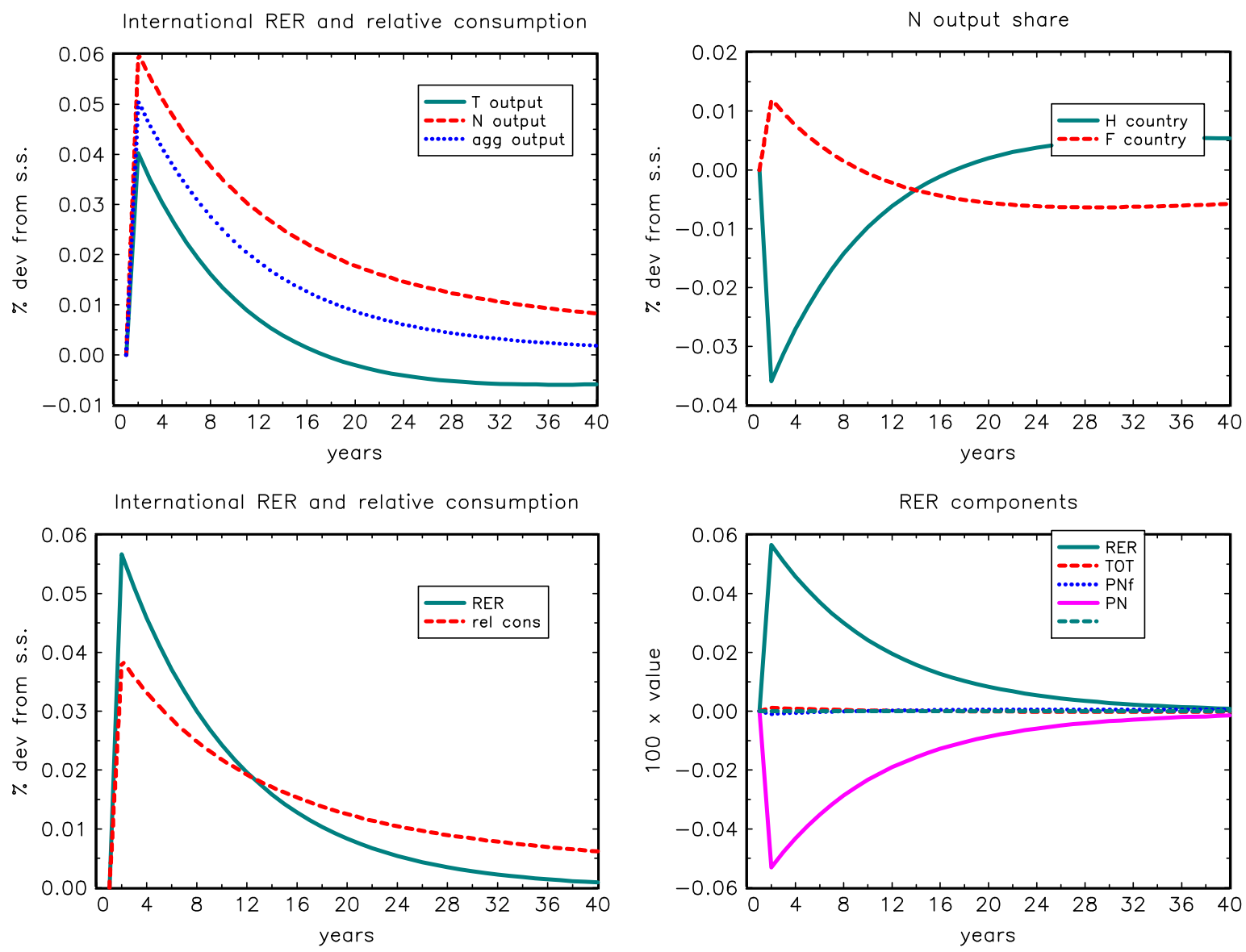

adjustments following $\mathrm{T}$ shocks, but moderate the adjustments following $\mathrm{N}$ shocks. This result becomes particularly important for Backus-Smith-Kollman correlation which depends very sensitively on the relative strength of the two sectoral shocks. Since $\mathrm{T}$ shocks produce a negative correlation between relative consumption and real exchange rate, and because the effects of these shocks are amplified in the presence of endogenous tradability the most, we find that Backus-Smith-Kollman correlation falls and thus becomes more aligned with the data in this version of the model. 


\section{Conclusion}

This paper has documented some previously neglected features of sectoral shares at business cycle frequencies in OECD economies, and has shown that while the standard international real business cycle model has difficulty in accounting for these properties of the data, the extended model which allows for sectoral adjustment along both the intensive and extensive margins does a much better job in replicating the volatilities and co-movements in the data. In addition, the model provides a closer match between theory and data with respect to the correlation between relative consumption growth and real exchange rate changes, a key measure of international risk-sharing. The model of the paper may be extended in a number of dimensions, such as allowing for physical capital accumulation, habit persistence in consumption preferences, and alternative sources of shocks. Doing so may improve the match between model and data. In its current form, however, the model suggests that the endogenous extensive margin of adjustment in open economies offers a rich vein of analysis in explaining properties of international business cycles. 


\section{References}

Backus, D. K., Smith, G. W., 1993. Consumption and real exchange rates in dynamic economies with non-traded goods. Journal of International Economics 35 (3-4), 297-316.

Benigno, G., Thoenissen, C., 2008. Consumption and real exchange rates with incomplete markets and non-traded goods. Journal of International Money and Finance 27 (6), 926-948.

Bergin, P. R., Glick, R., Sep 2005. Tradability, productivity, and understanding international economic integration. NBER Working Papers 11637, National Bureau of Economic Research, Inc.

Corsetti, G., Dedola, L., Leduc, S., 2008. International risk sharing and the transmission of productivity shocks. Review of Economic Studies 75 (2), 443-473.

Dotsey, M., Duarte, M., September 2008. Nontraded goods, market segmentation, and exchange rates. Journal of Monetary Economics 55 (6), 1129-1142.

Ghironi, F., Melitz, M. J., August 2005. International trade and macroeconomic dynamics with heterogeneous firms. The Quarterly Journal of Economics 120 (3), 865-915.

Kollmann, R., 1995. Consumption, real exchange rates and the structure of international asset markets. Journal of International Money and Finance 14 (2), 191-211.

Melitz, M. J., November 2003. The impact of trade on intra-industry reallocations and aggregate industry productivity. Econometrica 71 (6), 1695-1725.

Mendoza, E. G., 1995. The terms of trade, the real exchange rate, and economic fluctuations. International Economic Review 36 (1), 101-37.

Obstfeld, M., Rogoff, K., February 2000. The six major puzzles in international macroeconomics: Is there a common cause? In: NBER Macroeconomics Annual 2000, Volume 15. NBER Chapters. National Bureau of Economic Research, Inc, pp. 339412.

Pesenti, P., van Wincoop, E., 2002. Can nontradables generate substantial home bias? Journal of Money, Credit and Banking 34 (1), 25-50. 
Stockman, A. C., Tesar, L. L., 1995. Tastes and technology in a two-country model of the business cycle: Explaining international comovements. American Economic Review 85 (1), 168-185.

Tesar, L. L., 1993. International risk-sharing and non-traded goods. Journal of International Economics 35 (1-2), 69-89. 


\section{A Appendix}

\section{A.1 Data sources and calculations}

To construct data statistics reported in Table 4 we collect data from the OECD Main Economic Indicator (MEI) and OECD Quarterly National Accounts (QNA) for the period 1973-2007 and construct variables using the definitions summarized in Table A1.

Table A1: Data sources and calculations

\begin{tabular}{|c|c|c|}
\hline Variable & Definition & Source \\
\hline \multicolumn{3}{|l|}{ The U.S. } \\
\hline Output $\left(y_{1}\right)$ & Gross Domestic Product (at constant price 2000) & OECD MEI \\
\hline Consumption $\left(c_{1}\right)$ & $\begin{array}{l}\text { Private plus Government Final Consumption Expenditure } \\
\text { (at constant price 2000) }\end{array}$ & OECD MEI \\
\hline Employment $\left(l_{1}\right)$ & Civilian Employment Index & OECD MEI \\
\hline Real exchange rate $(r x)$ & Price-adjusted Broad Dollar Index & Board of Governors \\
\hline Import price & imports at current prices/imports at constant prices & OECD QNA \\
\hline Export price & exports at current prices/exports at constant prices & OECD QNA \\
\hline Terms of trade $(p)$ & import price/export price & \\
\hline Net exports ratio $(n x)$ & (import- $p^{*}$ export) $/ y_{1}$ (all at current prices) & \\
\hline \multicolumn{3}{|l|}{ Rest of the World } \\
\hline Output $\left(y_{2}\right)$ & $\begin{array}{l}\text { Aggregate of Canada, Japan and } 19 \text { European Counties } \\
\text { (aggregate with PPP exchange rates in 2000) }\end{array}$ & OECD MEI \\
\hline Consumption $\left(c_{2}\right)$ & $\begin{array}{l}\text { Aggregate of Canada, Japan and } 19 \text { European Counties } \\
\text { (aggregate with PPP exchange rates in 2000) }\end{array}$ & OECD MEI \\
\hline Employment $\left(l_{2}\right)$ & $\begin{array}{l}\text { Aggregate of Canada, Japan and } 8 \text { European Counties } \\
\text { (weighted with populations in 2000) }\end{array}$ & OECD MEI \\
\hline
\end{tabular}

The rest of the world variables are computed as the weighted aggregates of Canada, Japan and 19 European countries, including Austria, Belgium,Denmark, Finland, France, Germany, Greece, Ireland, Italy, Luxembourg, the Netherlands, Portugal, Spain, Sweden and United Kingdom, Iceland, Luxembourg, Switzerland and Turkey. The employment series for the rest of the world, because of data unavailability, is computed as the weighted aggregate of Canada, Japan and 8 European countries (Austria, Finland, Germany, Italy, Norway, Spain, Sweden and UK). 


\section{A.2 Derivation of consumption aggregates}

Consider the final consumption aggregate. It consists of internationally nontraded goods and a basket of internationally traded goods. The latter can be produced by local firms or imported from the foreign country. Recall that all local firms are located on $[0,1]$ interval. Firms that produce internationally nontraded goods occupy $\left[1, i^{*}\right]$ interval, where $i^{*}$ is the threshold export index in a given country. Domestic internationally-traded goods are produced by firms located on $\left(i^{*}, 1\right]$ interval. We append this continuum of local firms by a $\left[1,2-\imath^{*}\right]$ measure of foreign firms that can export their goods to the home country market. As a result, the consumption basket of households residing in country $\mathrm{H}$ becomes

$$
\begin{aligned}
C^{\phi}= & \left(i^{*}\right)^{1-\phi}\left[\int_{0}^{i^{*}}\left(\frac{1}{i^{*}}\right)^{1-\rho} c_{i}^{\rho} d i\right]^{\frac{\phi}{\rho}}+\left(1-i^{*}\right)^{1-\phi}\left[\left(\frac{1}{2-\hat{\imath}^{*}-i^{*}}\right)^{1-\rho}\left(\int_{i^{*}}^{1} c_{i}^{\rho} d i+\int_{1}^{2-\hat{i}^{*}} \hat{c}_{i}^{\rho} d i\right)\right]^{\frac{\phi}{\rho}} \\
= & \left(i^{*}\right)^{1-\phi}\left[\int_{0}^{i^{*}}\left(\frac{1}{i^{*}}\right)^{1-\rho} c_{i}^{\rho} d i\right]^{\frac{\phi}{\rho}}+\left(1-i^{*}\right)^{1-\phi} * \\
& *\left[\left(\frac{1}{2-\hat{i}^{*}-i^{*}}\right)^{1-\rho}\left(\left(1-i^{*}\right)^{1-\rho} \int_{i^{*}}^{1}\left(\frac{1}{1-i^{*}}\right)^{1-\rho} c_{i}^{\rho} d i+\left(1-\hat{\imath}^{*}\right)^{1-\rho} \int_{1}^{2-\hat{i}^{*}}\left(\frac{1}{1-\hat{i}^{*}}\right)^{1-\rho} \hat{c}_{i}^{\rho} d i\right)\right]^{\frac{\phi}{\rho}} \\
= & \left(i^{*}\right)^{1-\phi}\left(C^{\mathbb{N}}\right)^{\phi}+\left(1-i^{*}\right)^{1-\phi}\left[\left(\frac{1-i^{*}}{2-\hat{i}^{*}-i^{*}}\right)^{1-\rho}\left(C^{\mathrm{H}}\right)^{\rho}+\left(\frac{1-\hat{i}^{*}}{2-\hat{i}^{*}-i^{*}}\right)^{1-\rho}\left(C^{\mathrm{F}}\right)^{\rho}\right]^{\frac{\phi}{\rho}} \\
= & \left(i^{*}\right)^{1-\phi}\left(C^{\mathbb{N}}\right)^{\phi}+\left(1-i^{*}\right)^{1-\phi}\left(C^{\mathrm{T}}\right)^{\phi},
\end{aligned}
$$

where

$$
\begin{aligned}
\left(C^{\mathrm{N}}\right)^{\rho} & =\int_{0}^{i^{*}}\left(\frac{1}{i^{*}}\right)^{1-\rho} c_{i}^{\rho} d i, \\
\left(C^{\mathrm{H}}\right)^{\rho} & =\int_{i^{*}}^{1}\left(\frac{1}{1-i^{*}}\right)^{1-\rho} c_{i}^{\rho} d i, \\
\left(C^{\mathrm{F}}\right)^{\rho} & =\int_{1}^{2-i^{*}}\left(\frac{1}{1-\hat{i}^{*}}\right)^{1-\rho} \hat{c}_{i}^{\rho} d i .
\end{aligned}
$$

From above, consumption shares are endogenously linked to the threshold export index of firms:

$$
\begin{gathered}
\lambda_{\mathrm{N}}\left(i^{*}\right)=i^{*} \quad \text { and } \quad \lambda_{\mathrm{T}}\left(i^{*}\right)=1-i^{*}, \\
\lambda_{\mathrm{H}}\left(i^{*}\right)=\frac{1-i^{*}}{2-\hat{i}^{*}-i^{*}} \quad \text { and } \quad \\
\lambda_{\mathrm{F}}\left(i^{*}\right)=\frac{1-\hat{-}^{*}}{2-\hat{\imath}^{*}-i^{*}} .
\end{gathered}
$$




\section{A.3 International RER}

In order to derive the decomposition for international RER, we log-linearize aggregate consumption price indices as follows. The log-pice of aggregate price index in country $\mathrm{H}$ can be written as

$$
\begin{aligned}
p_{t} & =\lambda_{\mathrm{T}}\left(\frac{P^{\mathrm{T}}}{P}\right)^{\frac{\phi}{\phi-1}} p_{t}^{\mathrm{T}}+\lambda_{\mathrm{N}}\left(\frac{P^{\mathrm{N}}}{P}\right)^{\frac{\phi}{\phi-1}} p_{t}^{\mathrm{N}} \\
& =p_{t}^{\mathrm{T}}+\lambda_{\mathrm{N}}\left(\frac{P^{\mathrm{N}}}{P}\right)^{\frac{\phi}{\phi-1}}\left(p_{t}^{\mathrm{N}}-p_{t}^{\mathrm{T}}\right),
\end{aligned}
$$

with

$$
\begin{aligned}
p_{t}^{\mathrm{T}} & =\lambda_{\mathrm{H}}\left(\frac{P^{\mathrm{H}}}{P^{\mathrm{T}}}\right)^{\frac{\rho}{\rho-1}} p_{t}^{\mathrm{H}}+\lambda_{\mathrm{F}}\left(\frac{P^{\mathrm{F}}}{P^{\mathrm{T}}}\right)^{\frac{\rho}{\rho-1}} p_{t}^{\mathrm{F}} \\
& =p_{t}^{\mathrm{H}}+\lambda_{\mathrm{F}}\left(\frac{P^{\mathrm{F}}}{P^{\mathrm{T}}}\right)^{\frac{\rho}{\rho-1}}\left(p_{t}^{\mathrm{F}}-p_{t}^{\mathrm{H}}\right) .
\end{aligned}
$$

A similar set of conditions applies to the foreign country. We define international RER as a relative price of foreign to domestic consumption basket. Thus RER can be written as

$$
\operatorname{rer}_{t}=\hat{p}_{t}-p_{t}
$$

Substituting in the definitions above, we get

$$
r e r_{t}=\left(\lambda_{\mathrm{H}}-\lambda_{\mathrm{F}}\left(\frac{1}{1-\tau_{I}}\right)^{\frac{\rho}{\rho-1}}\right) \kappa_{1}\left(\hat{p}_{t}^{\mathrm{F}}-p_{t}^{\mathrm{H}}\right)+\hat{\lambda}_{\mathrm{N}} \kappa_{2}\left(\hat{p}_{t}^{\mathrm{N}}-\hat{p}_{t}^{\mathrm{T}}\right)-\lambda_{\mathrm{N}} \kappa_{2}\left(p_{t}^{\mathrm{N}}-p_{t}^{\mathrm{T}}\right)
$$

where lowercase letters, as before, denote the log transformations for all variables in deviations from their steady state values (e.g., $p_{t}^{\mathrm{H}} \equiv \ln P_{t}^{\mathrm{H}}-\ln P^{\mathrm{H}}$, etc.); and $\kappa_{1}^{\frac{\rho-1}{\rho}}=\left(\hat{P}^{\mathrm{F}} / P^{\mathrm{T}}\right), \kappa_{2}{ }^{\frac{\phi-1}{\phi}}=\left(\hat{P}_{\mathrm{A}}^{\mathrm{N}} / \hat{P}_{\mathrm{A}}\right)=\left(P_{\mathrm{A}}^{\mathrm{N}} / P_{\mathrm{A}}\right)$. This is expression $(6.16)$ in the text. 